\title{
$\square$
}

\section{Milton Friedman, 1912-2006: Some Personal Reflections}

William Poole

M

ilton Friedman died the week before Thanksgiving. In the days that followed, articles in major newspapers ably covered the tremendous importance of his work in economic science and his historic contributions to public policy. Throughout his career, Milton-everyone who knew him called him Milton-provided specific examples of how the magic of competitive markets could be brought to bear on public policy issues. Those examples, such as his successful advocacy of a volunteer army, taught many other economists to pursue the same approach on a wide range of issues.

But the recent articles on Milton did not adequately emphasize an important point. On numerous issues, Milton did not disagree with liberals on goals but he did disagree with them on the best policies to achieve those goals. $\mathrm{He}$ wanted, for example, to see children receive a good education. He simply believed that marketoriented approaches would work better than governmental approaches. Thus, he favored government-provided school vouchers, which could be tendered at private schools, rather than public schools. Similarly, he favored housing vouchers over public housing. This is an important point because many liberals have tended to dismiss Milton's approaches because they just could not believe that anyone could favor a goal and not favor a direct government approach to achieving the goal.

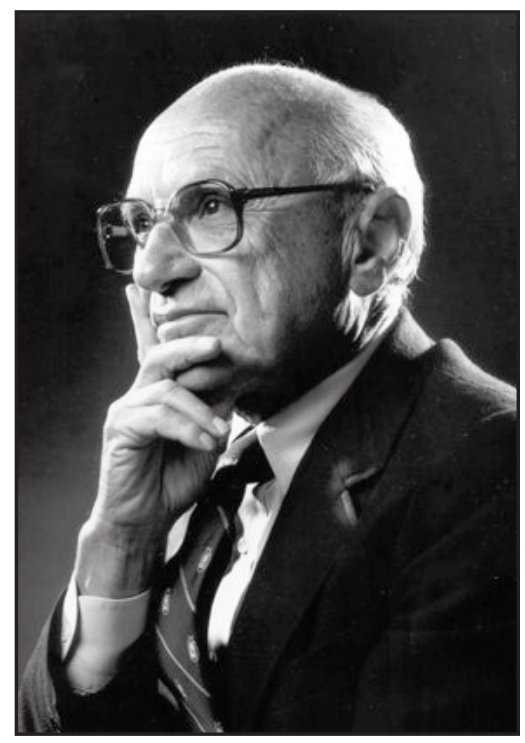

I heard Milton debate on many occasions. He typically destroyed his opponents in those debates-destroyed the case but not the person. His method was simple but always brilliantly executed. "Do you agree with these goals?"

Answer: "Yes." "Do you agree with these propositions from economic theory?" (An example would be that demand curves slope downward.) Answer: "Yes, I agree that demand curves slope downward." "Here are the facts as I see them-X, Y, and $\mathrm{Z}$. So, given that we agree on the goals, we agree on economic theories A, B, and C, facts X, $\mathrm{Y}$, and $\mathrm{Z}$, then logic takes us to these conclusions."

I heard more than one debate opponent, not liking the conclusions, tell Milton that "you are

William Poole is the president of the Federal Reserve Bank of St. Louis. The views expressed are the author's and do not necessarily reflect official positions of the Federal Reserve System.

Federal Reserve Bank of St. Louis Review, January/February 2006, 89(1), pp. 1-2.

(C) 2007, The Federal Reserve Bank of St. Louis. Articles may be reprinted, reproduced, published, distributed, displayed, and transmitted in their entirety if copyright notice, author name(s), and full citation are included. Abstracts, synopses, and other derivative works may be made only with prior written permission of the Federal Reserve Bank of St. Louis. 
taking logic too far." Milton would reply, "That is the only place you can take logic. If you do not like the conclusions, you'll have to find different premises."

Many have noted Milton's prowess in debate. I would add that he attacked his opponents' logic, or illogic, and not their person or motives. I know that he often believed that there were hidden motives or goals behind policy positions he did not accept, but in my experience, although he might discuss hidden motives in general, he would not try to ascribe them to a particular debate opponent. He kept debate on a high, impersonal level; he focused on ideas and logic and not persons.

When I went to the University of Chicago for graduate study in 1959, I audited Milton's price theory course my first semester and later became a member of his justly famous Money Workshop. Milton pushed his students, but was quite patient with them. He would pause in his presentations, seeking feedback and questions and engaging in conversation, trying to be sure that students understood whatever point he was making. Unlike some other professors I had over the years, he never made jokes at a student's expense. Occasionally he became exasperated with a student who continued with some inane argument and his exasperation would show. He was very generous with his time and as a student I made good use of his office hours.

Milton was on leave during my thesis-writing year at Chicago, but he got me started on my topic, the Canadian experience with floating exchange rates. For some years after I left Chicago, Milton would comment on drafts of papers I sent him. He was a mentor and I greatly appreciated the time he took to help me sharpen my analysis.

I was privileged to be Milton's student and to have maintained contact with him over a span of almost 50 years. We have lost a giant intellect and a fine human being. 